Most of the papers that were given at the Congress were, naturally, devoted to work on spiders, as were nearly all the posters; but scorpions also attracted a considerable amount of attention. On the Thursday, an excursion was arranged to the nearby archipelago aboard s/s Ukopekka, while the Congress Dinner was held on Friday at Hotel Pargas, Parainen. The Concluding Ceremonies included a general meeting of CIDA (Centre International de Documentation Arachnologique), at which Dr Konrad Thaler, of Innsbruk, Austria, having served his term as President, was replaced in that office by Dr Volker Mahnert, from Geneva, Switzerland.

A post-congress excursion to the S.W. Archipelago was conducted by Dr Pekka T. Lehtinen, Chairman of the Local Organizing Committee, and one to Lapland by Dr Seppo Koponen, the Secretary, and his wife Heli. This was the one attended by the present writer and his own wife. We flew to Ivalo and were taken by bus to Saariselkä, where we spent the night: the following day we went by bus via Ivalo, Inari, and Kaamanen, to the Kevo Subarctic Research Station of the University of Turku in Utsjoki, where we stayed for three nights, and whence we visited Nesseby and Valsø on Varangerfjord which leads into the Barents Sea. Throughout our visit the weather was warm and sunny, giving no hint of the winter cold to follow!

Finland retains more of its natural vegetation than most European countries, and this was evident wherever we went. The Kevo Research Station, situated on Lake Kevojärvi in the commune of Utsjoki, the northernmost municipality in Finnish Lapland $\left(69^{\circ} 45^{\prime} \mathrm{N}, 27^{\circ} \mathrm{E}\right)$, lies about 60 $\mathrm{km}$ north of the line of continuous pine forest and belongs rather to the forest tundra zone-actually a birch subzone of the boreal coniferous forest. The coldest month is January (average $-16^{\circ} \mathrm{C}$ ), the warmest July (average $+13^{\circ} \mathrm{C}$ ), and the annual mean is $-2^{\circ} \mathrm{C}$. Snow cover lasts until about 20 May: there is no permafrost but in some bogs the palsas contain small isolated ice-lenses. The most important animal in the general 'ecosystem' is the Reindeer (Rangifer tarandus). Other large mammals are rare: they include Elk/Moose (Alces alces), Wolverine (Gulo gulo), Arctic Fox (Alopex lagopus), Wolf (Canis lupus), and Bear (Ursus arctos). The worst season of mosquitoes (Culicidae) and blackflies (Simuliidae) was almost over at the time of our excursion.

The entire Congress was a model of good organization, careful planning, interesting presentations, and unusual food and drink - blended with an opportunity to visit ecobiomes that were unfamiliar to many of those who attended. Not surprisingly, it was extremely successful.

JOHN L. CLOUDSLFY-THOMPSON

Department of Biology (Medawar Building) University College London

Gower Street, London WCIE 6BT, UK.

\section{IUCN Species Survival Commission Meeting held In the InSTITUTE OF ANimal and Human Biology, UNIVERSITY OF ROME, ROME, ITALY, DURING 20-22 August 1989}

The Species Survival Commission of IUCN concluded this, its 64th meeting, having taken a major step towards addressing the challenges of species' conservation throughout the world. Sponsored by IUCN-The World Conservation Union-this meeting brought together over 230 specialists representing more than 80 groups concerned with saving 'endangered, vulnerable, and rare' animals and plants. The 40-odd papers which were presented covered topics ranging from orchids, goldenrods, and milkweeds, to civet otters, Liberian mongooses, coral-reef butterfly fish, cetaceans, Javan rhinos, and the banana slug.

Dr George B. Rabb, Director of the Chicago Zoological Society, and the incoming Chairman of the Commission, emphasized the new approach of the scientific community which was clearly reflected in the discussions:

'In the past, scientists felt that identifying the problem was enough. We focused on animal population dynamics-and we must continue to do so. However, we now realize that the human dimension, with political and economic factors, must be included alongside the biology in our Action Plans. We have to address policymakers at a national level, based on the interest of their people in maintaining the world's natural heritage. When we talk about "endangered, vulnerable, indeterminate and rare species", we have to do it in more meaningful terms. We need precise methods for predicting this or that animal's survival capacity.'

To the question of whether the exchange of ideas and experiences in Rome 'could save a species', Dr Rabb said he thought 'quite a few species will be saved by our coming to grips with the political and socio-economic aspects of species survival efforts. Unless we provide for environmental security, we are going to have economic, social, and political, insecurity with us for ever.'

The undersigned, Coordinator of IUCM's Species Conservation Programme, emphasized that the meeting was "not an academic exercise. [All the time], governments ask us to advise them on species and to help protect them. We are obliged to be practical.

\section{STEPHEN R. EDWARDS \\ The World Conservation Union (IUCN) Avenue du Mont-Blanc 1196 Gland, Switzerland.}

Regional Meeting of National MAB Committees of Arab States, held at the Institute of Higher Studies and RESEARCH, UNIVERSITY OF AleXandRIA, EGYPT, 2-6 SEPTEMBER 1989

The idea of holding a regional meeting for National MAB Committees of Arab States was proposed by the Egyptian Committee, in cooperation with the UNESCO/MAB (Man and Biosphere Programme) Secretariat and the Regional Office for Science and Technology for Arab States (ROSTAS) of UNESCO, based in Cairo. The purposes of such a meeting were: (1) to review and discuss activities carried out in the Arab region under the umbrella of the MAB Programme, (2) to encourage current projects, (3) to promote cooperation among Arab countries in this field, (4) to develop and activate new projects, and finally (5) to consider the four new MAB orientations (approved by the MAB International Coordinating Council at its Eighth Session in October 1986), from the point of view of the needs of Arab countries. Several Arab countries had already participated in two similar meetings, one for Mediterranean countries in Montpellier in 1976, and the other for Francophone African countries in Yamassoukro in 1984. Two other, similar, meetings were also held for North American and Western European countries in Berchtesgaden in 1987, and for Western and Eastern European countries, also in 1987.

Invitations were issued to Natioinal MAB Committees of Arab States, and to National UNESCO Commissions where a MAB Committee is non-existent, to participate 